\title{
REAL-TIME PCR TO IDENTIFY PORCINE DNA IN PROSTHODONTIC MATERIALS
}

\begin{abstract}
Objectives: This study aimed to identify porcine DNA in prosthodontic materials using Real-Time PCR.

Materials and methods: Eighteen prosthodontic materials: three irreversible hydrocolloids, three elastomers, three denture adhesives, three soft denture linings, three temporary crowns, and three denture bases materials were used as the samples. It was conducted in two stages. First, extraction of dental material's DNA and the second was Real-Time PCR analysis based on amplification curve and Ct score in yellow and green channel.
\end{abstract}

Results: The sample analysis based on green channel demonstrated that all materials did not contain porcine DNA, however, 11 of 18 samples (DA-01, DA-02, DA-03, SDL-02, DB-01, DB-02, TC-03, IH-02, EM01, EM-02, and EM-03) contained vertebrate DNA.

Conclusions: All prosthodontic materials tested were not containing porcine. The halal statues of the materials were still unclear.

Keywords: Pcr, Porcine DNA, prosthodontic materials.

\author{
(D) Ismail Hutasoit ${ }^{1}$ \\ (D) Fitri Ramadhani Munthe ${ }^{1}$ \\ (D) Masna Wiyah ${ }^{1}$ \\ (D) *Hubban Nasution ${ }^{1}$ \\ (D) Agy Wirabudi Pranata ${ }^{2}$
}

ORCID IDs of the authors:
$\begin{array}{ll}\text { I.H. } & 0000-0002-5353-1994 \\ \text { F.R.M. } & 0000-0002-0121-4014 \\ \text { M.W. } & 0000-0001-5971-6511 \\ \text { H.N. } & 0000-0002-0627-3523 \\ \text { A.W.P. } & 0000-0002-9541-7209\end{array}$

\footnotetext{
${ }^{1}$ Department of Prosthodontics, Faculty of Dentistry, Universitas Sumatera Utara, Medan, Indonesia.

${ }^{2}$ Halal Science Center, Institut Pertanian Bogor, Bogor, Indonesia.
} 


\section{INTRODUCTION}

Indonesia is the biggest Muslim-populated country worldwide where more than 200 million Indonesian people are Muslims. ${ }^{1}$ Currently, halal product demands increase globally not only for food and beverages but also encompass pharmaceutical products such as vaccines, medicines, and dental materials. ${ }^{2}$ A positive response regarding halal problems, primarily regarding food, medicines, and cosmetics, has been projected by the Indonesian government by publishing several legislations, one of which is Law No. 33 of 2014 on Halal Product Guarantee (UUJPH). ${ }^{3,4}$

Halal Product Guarantee (UUJPH) underlines that all products entering, circulating, and traded in Indonesia should have halal certificates. However, these regulations were made partially, inconsistently, overlapping, and nonsystematically. Hence, technically, they could not be enforced as robust legal protection and specifically bound the halal product matter to producers (business actors) and provide a guarantee to customers. It contributed to the absence of legal certainty guarantee regulating halal products, whereas the need for halal product guarantee is urgent, particularly concerning customer protection and global trade scenes. Some of the products maybe contained non-halal product without listed by manufacturer, doesn't have halal certificate, and unclear information about ingredients of the product. ${ }^{5,6}$ Halal status of dental materials traded in Indonesia remains to be doubtful if there is no guarantee from producers by the halal logo. ${ }^{7}$

Technological advances in the halal analysis field continued improving to detect halal materials contaminated by haram materials. Several plausible tests to distinguish various porcine content in a product are by identifying proteins, fats, and Deoxyribonucleic Acid (DNA). ${ }^{89}$ The DNA analysis based on DNA can use conventional polymerase chain reaction (PCR) and Real-Time PCR. Deoxyribonucleic acid is nucleic acid polymers systematically arranged, a stable molecule in the extraction process found in all cell types of animals with identical genetic information.
Deoxyribonucleic acid analysis in a product can be performed using Real-Time PCR by amplification DNA. ${ }^{10,11,12}$ The advantages of Real-Time PCR are the samples can be analyzed in a small amount and produced rapidly and accurately. ${ }^{13,14,15}$

Studies concerning halal tests on dental materials have been conducted. In 2016, a study was conducted on periodontal materials. In the study, the researchers argued that medication and non-halal material usage were the requirements during emergency situations and only in particular conditions and limitations. As an alternative, BioGide $^{\circledR}$, Emdogain $^{\circledR}$, and Bio-Oss ${ }^{\circledR}$ products can be used in periodontal surgery treatments because they are halal medicines. However, the study suggested that periodontal specialists and fikh experts should improve their collaborations to understand fikh principles to be consulted in each legal issue, especially in modern dental treatments. ${ }^{16}$ In 2017, a study was carried out on gelatin rapid testing in dental materials using the Attenuated Total Reflection Fourier Transform Infrared Spectroscopy (ATR-FTIR). The study utilized 42 samples classified into homeostatic agents, restoration materials, prophylaxis materials, oral surgery materials, dental impressions, anesthetic agents, oral rinse, prosthodontic materials, and preventive materials. The study results asserted that none of the 42 samples were identified containing gelatin, with most samples were categorized as homeostatic agents. Several homeostatic agents used in dental services were sourced from bovine and porcine gelatin. ${ }^{17}$ In 2017, a halal test on dental materials in orthodontics on 21 samples was performed. The results demonstrated no dental materials in orthodontics displaying a $100 \%$ resemblance with porcine gelatin spectrum tested. However, a further test should be employed for the halal test for these materials. ${ }^{18}$ In 2020, a study on porcine gelatin identification on dental materials using the combination of Attenuated Total ReflectionFourier Transform Infrared Spectroscopy (ATRFTIR) and Chemometrics showed that four of 49 dental materials used in dental hospitals and clinics contained gelatin. One of them tended to resemble porcine gelatin, while the other three could not be 
identified. The gelatin in the product acted as an emulsifier and added in a small amount. ${ }^{19}$

Dental materials are an integral part of every dental service. ${ }^{21}$ Dental material is a study regarding materials used in dentistry which can be categorized into four classes, i.e., metals, ceramics, composites, and polymers. ${ }^{21}$ Dental material studies, particularly in prosthodontics, have been studied vastly. However, to date, there are only limited identifications on porcine content in prosthodontic materials. ${ }^{21,22}$ Therefore, the purpose of this study was to identify the porcine DNA in prosthodontic materials using Real-Time PCR.

\section{MATERIALS AND METHODS}

The study was carried out in Halal Science Center of Institut Pertanian Bogor. Three irreversible hydrocolloids, three elastomers, three denture adhesives, three soft denture linings, three temporary crowns, and three denture bases materials $(n=18)$ were examined (Table 1$)$.

Table 1. List of Samples

\begin{tabular}{llll}
\hline No & Code & Category & Manufacturer Country \\
\hline 1 & DA-01 & Denture adhesives & United Kingdom \\
2 & DA-02 & Denture adhesives & Austria \\
3 & DA-03 & Denture adhesives & Singapore \\
4 & SDL-01 & Soft denture lining & Japan \\
5 & SDL-02 & Soft denture lining & Germany \\
6 & SDL-03 & Soft denture lining & Germany \\
7 & TC-01 & Temporary crown & USA \\
8 & TC-02 & Temporary crown & Korea \\
9 & TC-03 & Temporary crown & USA \\
10 & DB-01 & Heat polymerized acrylic resin & Brazil \\
11 & DB-02 & Heat polymerized acrylic resin & Japan \\
12 & DB-03 & Heat polymerized acrylic resin & China \\
13 & IH-01 & Irreversible hydrocolloid & Italy \\
14 & IH-02 & Irreversible hydrocolloid & Japan \\
15 & IH-03 & Irreversible hydrocolloid & USA \\
16 & EM-01 & Elastomer & Japan \\
17 & EM-02 & Elastomer & Korea \\
18 & EM-03 & Elastomer & USA \\
\hline
\end{tabular}

Approval of the Scientific Research Committee of Universitas Sumatera Utara with ID: 205/KEP/USU/2020.

Each sample consists of 20 milligram/ material. The sampling technique used was the purposive sampling based on predetermined inclusion and exclusion criteria. All samples were analyzed using Real-Time PCR (Rotor-Gene Q D40724, Qiagene, Hilden, Germany). The study was divided into two stages. First, extraction of dental material's DNA and the second was Real-Time PCR analysis based on amplification curve and $\mathrm{Ct}$ score in yellow and green channel. ${ }^{23}$

Before entering the initial stage, pre-running was carried out. All samples were extracted using EasyFast ${ }^{\mathrm{TM}}$ Extra Pharma I (Ph.Ext1, Progenus s.a., Gembloux, Belgium). DNA extraction products were detected using Kit Progenus EasyFast ${ }^{\mathrm{TM}}$ Pharma Pig/Suidae detection \& quantification kit
(EFPig50/100, Progenus s.a., Gembloux, Belgium) and analyzed using Real-Time PCR. ${ }^{23}$

The initial DNA extraction stage aimed to obtain a DNA solution. After obtaining DNA solution, the samples were added with a buffer on $65^{\circ} \mathrm{C}$ for 10 minutes, added with precipitation buffer in ice for 5 minutes, centrifuged for 2 minutes at $12.000 \mathrm{rpm}$, added with binding buffer and centrifuged for 1 minute at $12.000 \mathrm{rpm}$, added with washing buffer I at $12.000 \mathrm{rpm}$, heated in elution buffer on $65^{\circ} \mathrm{C}$, and incubated on $65^{\circ} \mathrm{C}$ at $12.000 \mathrm{rpm}$. The second stage after obtaining the DNA solution was analyzed with repetition of 40 cycles. This stage was carried out using MIX solution (EFPig50, Progenus s.a., Gembloux, Belgium), Nuclease free water (EFPig50, Progenus s.a., Gembloux, Belgium) as the negative control, External Positive Control/EPC solution (EFPig50, Progenus s.a., Gembloux, Belgium) as the positive control with an initial temperature of $95^{\circ} \mathrm{C}$, 
followed by denaturation temperature of $95^{\circ} \mathrm{C}$, and annealing temperature of $60^{\circ} \mathrm{C}$. Data analyses were then carried out based on VIC (yellow channel)/ vertebrate and FAM (green channel)/porcine reporters. The yellow channel was used to detect the presence or absence of vertebrate DNA in the sample while the green channel was used to detect the presence or absence of porcine DNA in the sample. ${ }^{23}$
The sample was tested positive for porcine DNA if there was a Ct value; the sample curve line was above the threshold line on the green channel amplification graph and follows the positive control line on the amplification curve. The program of Real-Time PCR was set and the tubes containing the sample and control were inserted into the machine then run according to the RealTime PCR program. ${ }^{23}$ (Table 2)

Table 2. Set Program of RT - PCR

\begin{tabular}{llll}
\hline Step & Time & Temperature & Comment \\
\hline Initial PCR activation step & $5 \mathrm{~min}$ & $95^{\circ} \mathrm{C}$ & $\begin{array}{l}\text { Activation of HolStar Taq } \\
\text { Plus DNA polymerase }\end{array}$ \\
3 Step cycling: & & & \\
Denaturation & $15 \mathrm{~s}$ & $95^{\circ} \mathrm{C}$ & \\
Annealing & $15 \mathrm{~s}$ & $60^{\circ} \mathrm{C}$ & Data collection of $60^{\circ} \mathrm{C}$ \\
Extension & $10 \mathrm{~s}$ & $72^{\circ} \mathrm{C}$ & \\
Number of cycles & 40 & & \\
Detection & Reporter & $495 / 520 \mathrm{~nm}$ & Channel \\
Target & FAM & $524 / 557 \mathrm{~nm}$ & Green \\
Internal control & MAX & & Yellow \\
* FAM (fluorescein amidets) & & & \\
MAX (Master Mix) & & &
\end{tabular}

\section{RESULT}

The study results demonstrated that no porcine DNA was identified in the samples, where DNA amplification results based on the FAM (green channel) reporter did not report curve elevation on all tested samples, and no $\mathrm{Ct}$ values with porcine primers were found on each sample (Table 3). However, several tested dental materials contained vertebrate DNA.

Table 3. Ct value of sampels using yellow channel (identification of vertebrate DNA)

\begin{tabular}{lcccc}
\hline No & Flour & Target & Samples & Ct Values \\
\hline 1 & VIC & Vertebrate & Negative Control & 32,88 \\
2 & VIC & Vertebrate & Positive Control & 30,08 \\
3 & VIC & Vertebrate & DA-01 & 39,53 \\
4 & VIC & Vertebrate & DA-02 & 32,41 \\
5 & VIC & Vertebrate & DA-03 & 35,17 \\
6 & VIC & Vertebrate & SDL-02 & 37,62 \\
7 & VIC & Vertebrate & DB-01 & 32,66 \\
8 & VIC & Vertebrate & DB-02 & 34,33 \\
9 & VIC & Vertebrate & TC-03 & 35,89 \\
10 & VIC & Vertebrate & IH-02 & 35,66 \\
11 & VIC & Vertebrate & EM-01 & 33,64 \\
12 & VIC & Vertebrate & Negative Control & 28,11 \\
13 & VIC & Vertebrate & Positive Control & 34,08 \\
14 & VIC & Vertebrate & EM-02 & 33,51 \\
15 & VIC & Vertebrate & EM-03 & \\
\hline VIC & & & & \\
\hline
\end{tabular}


The present study showed that 11 of 18 samples (DA-01, DA-02, DA-03, SDL-02, DB-01, DB-02,
TC-03, IH-02, EM-01, EM-02, and EM-03) contained vertebrate DNA, as presented in Table 4.

Table 4. Contents of Vertebrate DNA

\begin{tabular}{|c|c|c|c|}
\hline No & Code & Category & VIC \\
\hline 1 & DA-01 & Denture adhesives & + \\
\hline 2 & DA-02 & Denture adhesives & + \\
\hline 3 & DA-03 & Denture adhesives & + \\
\hline 4 & SDL-01 & Soft denture lining & - \\
\hline 5 & SDL-02 & Soft denture lining & + \\
\hline 6 & SDL-03 & Soft denture lining & - \\
\hline 7 & TC-01 & Temporary crown & - \\
\hline 8 & TC-02 & Temporary crown & + \\
\hline 9 & TC-03 & Temporary crown & - \\
\hline 10 & DB-01 & Heat polymerized acrylic resin & + \\
\hline 11 & DB-02 & Heat polymerized acrylic resin & + \\
\hline 12 & DB-03 & Heat polymerized acrylic resin & - \\
\hline 13 & IH-01 & Irreversible hydrocolloid & - \\
\hline 14 & IH-02 & Irreversible hydrocolloid & + \\
\hline 15 & IH-03 & Irreversible hydrocolloid & - \\
\hline 16 & EM-01 & Elastomer & + \\
\hline 17 & EM-02 & Elastomer & + \\
\hline 18 & EM-03 & Elastomer & + \\
\hline
\end{tabular}

*+(Vertebrate DNA)

- (No vertebrate DNA)

Detection results based on the VIC reporter (yellow channel) showed that DA-01 (Ct 39,53), DA-02 (Ct 32,41), DA-03 (Ct 35,17), SDL-02 (Ct 37,62), DB-01 (Ct 32,66), DB-02 (Ct 34,33), TC-03 (Ct 35,89), IH-02 (Ct 35,66), EM-01 (Ct 33,64), EM02 (Ct 34,08) and EM-03 (Ct 33,55) have significantly elevated curves over the threshold line (Figure 1).

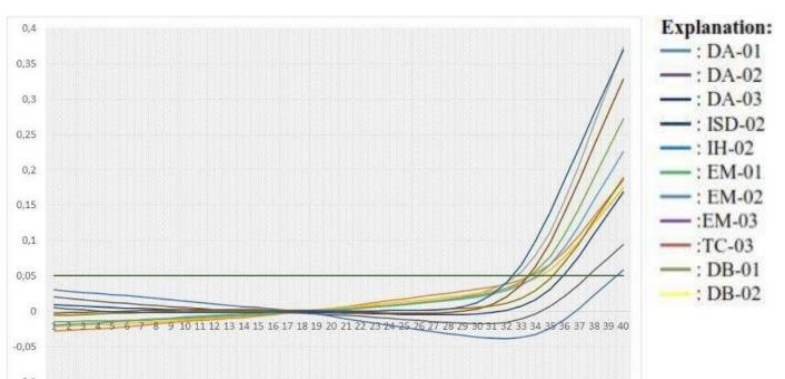

Figure 1. Sample amplification based on the VIC reporter (vertebrate detection)

These Ct values were obtained from the control positive curve passing over the threshold line and the number of cycle.

\section{DISCUSSION}

The halal status of prosthodontics materials is a necessity for Muslim patient. In the present study, porcine DNA was not detected in all samples, where the DNA amplification based on FAM reporter (green channel) did not discover curve elevation and $\mathrm{Ct}$ values with a porcine primer on each sample. However, 11 samples were having vertebrate DNA.

Amplifications using PCR Real-Time in the study was conducted for 40 cycles to obtain accurate results. During the amplification, the probe's fluorescence signal increased, and therefore, the signal significantly increased over the threshold line. This value was recorded as $\mathrm{Ct}$ (cycle threshold), where the larger the target DNA initial quantity, the lower the $\mathrm{Ct}$ value, and vice versa. Ct values aimed to discover the PCR RealTime validity according to the detection parameter 
and discovered whether study samples contain vertebrate or porcine DNA. ${ }^{23,24}$

Positive and negative controls demonstrated valid results according to the kit, where Cq FAM and VIC +30 for the positive control and Cq FAM and VIC $>38$ for the negative control. Based on amplification results that shown in Figure 1, in sample tests conducted, 11 of 18 samples contained vertebrate DNA. The External Positive Control (EPC), as the study's positive control, experienced a significantly increased amplification curve over the threshold line. Besides EPC, there was the NonTemplate Control (NTC) as the negative control. ${ }^{31}$ Negative control utilization showed that utilized reagents were not contaminated by target DNA to be amplified. Theoretically, the negative control curve did not show curve elevation; however, nine of 18 samples (DA-01, DA-02, DA-03, TC-02, TC3, DB-03, IH-01, IH-03, and EM-03) experienced curve elevation due to unknown external contaminations. Contaminations might be caused by incautious pipetting techniques or during tube insertion into the PCR Real-Time equipment, or from the analyst DNA adhering in the study site and carried by aerosols. Nevertheless, the study was declared valid because only the VIC reporter (yellow channel) experiencing contaminations while the FAM reporter (green channel) to detect porcine DNA had no $\mathrm{Ct}$ values indicating contaminations. ${ }^{23,24,25}$

Similar result were also obtained by Aziz in 2017 , a study was carried out to detect the presence of gelatin in orthodontic dental materials for halal authentication. ${ }^{7}$ The detection of gelatin was done using Fourier Transform Infrared Spectroscopy with Attenuated Total Reflectance (FTIR-ATR). In the study, 21 samples were included and the spectrums were generated by OMNIC software of Nicolet iS50 FTIR. All data were subjected to similarity match (SM) using TQ Analyst software. From the study, it was found that no samples exhibit similar spectra as the gelatin tested and SM found that no samples showed $100 \%$ similarities with porcine gelatin. ${ }^{7}$ On the other hand, present study was not in line with the research conducted by Dewi N (2020) where the examination of pork gelatin was carried out using Attenuated Total
Reflection-Fourier Transform Infrared Spectroscopy (ATR-FTIR) and Chemometrics. ${ }^{19}$ The obtained results were four of the 49 dental materials used in hospitals and clinics contained gelatin, one of which was included in pork gelatin while the three could not be identified. ${ }^{19}$

There are many analysis methods currently used, including Enzyme-Linked Immunosorbent Assay (ELISA), Real-Time Polymerase Chain Reaction DNA (RT-PCR), Gas Chromatography (GC), Gas Chromatography-Mass Spectrophotometry (GC-MS), Fourier Transform-Infrared. Spectroscopy (FTIR). Several methods have been developed with many methods using protein, fat and DNA. Analysis based on protein content in porcine can use porcine detection kits with an immunochromatography method, i.e., a combination of enzyme-linked immunosorbent assay (ELISA) and chromatography. ${ }^{26,27}$ However; this method has a disadvantage because the protein will lose its biological activity after the animal dies. In addition, the ineffective nature of protein after meat undergoes high processing caused by denaturation at high temperatures and high pressures hinders the analysis process. $^{28,29}$ Infrared spectroscopy, differential scanning calorimetric, gas chromatography, highperformance liquid chromatography (HPLC), and electronic odor detector can be used for analysis based on fat content. ${ }^{10,11}$ While the PCR method has a target, namely DNA, this method that is considered the most valid at this time. PCR is one of the most studied and widely used in vitro nucleic acid amplification techniques. PCR is used to multiply the number of DNA molecules on a specific target by analyzing new DNA molecules that complement the target DNA molecule via enzymes and oligonucleotides as primers in a thermo cycle. ${ }^{10}$ Molecular biology analysis, especially DNA by using PCR, has advantages compared to proteins or other molecules, because of the fact that DNA is more stable. ${ }^{10,11}$

In Real-Time PCR, the amount of DNA product formed can be monitored in real time, i.e., during the course of the reaction, with accuracy and high sensitivity over a dynamic range. ${ }^{9}$ This monitoring can be assisted by the use of fluorescent dyes or probes applied into the reaction. The 
fluorescence intensity of these probes will be proportional to the amount of DNA product formed. ${ }^{9}$ Moreover, in Real-Time PCR the number of amplification cycles required to obtain a particular amount of DNA molecules is recorded. ${ }^{10,11}$ Assuming a certain amplification efficiency, which is typically close to double the number of molecules per amplification cycle, the number of DNA molecules carrying the target sequence that were initially present in the sample can be calculated. ${ }^{11}$ A number of highly efficient chemistry detection, sensitive instrumentation, and optimized assays are now available that allow quantification of the number of DNA molecules of a particular sequence in a complex sample with unprecedented accuracy and sensitivity that can detect a single molecule. ${ }^{10,11}$

The study should be carried out with caution, and performed repetitively to ensure that the results were correct. The researchers only tested 18 prosthodontic materials in the market, and thus, the study results could not represent prosthodontic materials in general. In this study, the species of the vertebrate DNAs were not known. Further study was required to examine the halal status of dental materials. $^{28}$

\section{CONCLUSIONS}

The study concluded that no porcine DNA was detected in all samples. However, 11 of 18 samples were containing vertebrate DNA (non-porcine). The halal status of the materials tested remained unclear.

\section{ACKNOWLEDGEMENTS}

The authors gratefully acknowledges for Mr. Agy Wirabudi and Mrs. Lulu Dwiana at the Halal Study Center of Institut Pertanian Bogor for assisting this research.

\section{CONFLICTS OF INTEREST}

The authors declare no conflicts of interest.

\section{REFERENCE}

1. Rahardian B, Hakim N, Kurniawan A. Implementation of halal product guarantee in dental health services in islamic hospital. Int $\mathbf{J}$ Human and Health Sci 2019;3:54-7.

2. Corona B, Lleonard R, Carpio Y, Uffo O, Martinez. Short communication. PCR detection of DNA bovine, ovine-caprine and porcine origin in feed as part a bovine spongiform encephalopathy control program. Span J Agric Res 2017;5:312-7.

3. Charity ML. Halal products guarantee in Indonesia. Jurnal Legislasi Indonesia 2017;14: 1.

4. JM Muslimin. Halal product guarantee in Indonesia regulation and social inclusion. Journal of Economics and Business 2019;4:27-29.

5. Khan MI, Haleem A. Understanding "halal" and "halal certification \& accreditation system"- brief review. Saudi J Bus Manag Stud 2016;1:32-42.

6. Nafis MC. The concept of halal and thayyib and its implementation in Indonesia. Journal of Halal Product and Research 2019;2:1-5.

7. Aziz AH, Ab Mutalib NA, Rahman RA, Jaswir I, Mirgani ME, Octavianti F, et al. The authentication of halal dental materials using rapid fourier transform infrared (FTIR) spectroscopy. Adv Sci 2017;23:1-4.

8. Ali ME, Sultana S, Hamid SBA, Hossain M, Yehya WA, Kader MA, et al. Gelatin controversies in food, pharmaceuticals, and personal care product: authentication methods, current status, and future challenges. Critical Reviews in Food Science and Nutrition 2017; 58.1-10.

9. Ali ME, Kashif M., Uddin K, Hashim U, Mustafa S, Man YB. Species authentication methods in foods and feeds: the present, past, and future of halal forensics. Food Anal. Methods 2012;5:946.

10. Erwanto Y, Rohman A, Arsyanti L, Pranoto Y. Identification of pig DNA in product using polymerase chain reaction (PCR) for halal authentication-a review. IFRJ 2018;25:22-31.

11.Zilhadia, Izzah AN, Betha OS. Comparison of SYBR green and hydrolysis probe in analyzing porcine and bovine gelatin DNA using real-time PCR. J Sains Farm Klin 2017;4:16-23.

12. Salamah N, Erwanto Y, Martono S, Rohman A. Real-time PCR based detection of bovine DNA by specific targeting on cytochrome-B. Pharmaciana 2019;9:201-204.

13. Karuniawati A, Yasmon A, Ningsih I. Optimizing real-time PCR method to detect Leptospira spp. in human blood and urine specimens. Med J Indonesia 2012;21:13-14.

14. Sudjadi, Wardani HS, Sepminarti T, Rohman A. Analysis of porcine gelatin DNA in a commercial capsule shell using real-time polymerase chain reaction for halal authentication. Int J Food Prop 2016;19:21-34. 
15. Widayat, Agustini TW, Suzery M, Al-Baarri AN, Putri SR, Kurdianto. Real-time polymerase chain reaction (RT-PCR) as a tool for detecting pig DNA in non-food products. IJH 2019;2:27-29.

16. Halib N, Suhaila NS, Fattah WA, Ramli H, Abdul Ghaffar NA, Ahmad S. Islam and technological development in Malaysia's health care: an Islam legal basis analysis of dental material used in periodontal therapy. Malaysian Journal of Society and Space 2016;12:88-95.

17. Roswiem AP, Mustaqimah DN. Identification of gelatin source in toothpaste products using combination of attenuated total reflection-fourier transform infrared (ATR-FTIR) spectroscopy and chemometrics. Int J Halal Res 2020;2:30-37.

18. Ifranita N, Jaswir I, Mirghani MES, Sukmasari S, Ardini YD, Lestari W. Rapid detection of gelatin in dental materials using attenuated total reflection fourier transform infrared spectroscopy (ATR-FTIR). Journal of Physics: Conference Series. 2017;884:1-10.

19. Dewi N, Mustaqimah, Roswiem AP. Identification of gelatin in dental materials using combination of attenuated total reflection-fourier transform infrared spectroscopy (ATR-FTIR) and chemometrics. Int J Halal Res 2020;2:1-15.

20. Salim M. Contemporary islamic law in Indonesiasharia and legal pluralism. Edinburgh: Edinburgh University Press 2015;6:23-27.

21. Anusavice K, Shen C, Rawls HR General classes and properties of dental material (12th ed). Philips's science of dental materials. Missouri: Elsevier 2013:5-6.

22. Sakaguchi R, Powers J, Ferancee J. Craig's restorative dental materials (14th ed). Restorative materials: Resin composite and polymer. India: Mosby Elsevier 2009;150-204.

23. Firma NW, Azizah Z, Asra R. Pork DNA contamination in pharmaceutical product: a review. AJPRD 2020;8:96-100.

24. Hermanto S, Sumartin LO, Fatimah W. Differentiation of bovine and porcine gelatin based on spectroscopic and electrophoretic analysis. J Food Pharm Sci 2013;1:68-73.

25. Lee JH, Yi GY, Lee JW. Physicochemical characterization of porcine bone-derived grafting material and comparison with bovine xenografts for dental applications. J Periodontal Implant Sci 2017;47:388.

26. Rocha AJ, Monteiro-Júnior JE, Freire JEC, Sousa AJS, Fonteles C. Real-time PCR: the use of reference genes and essential rules required to obtain normalization data reliable to quantitative gene expression. J Mol Biol 2015;5:45-55.

27. Loftis AD, Reeves WK, Wang C, Kaltenboeck B, Freeman MD. Principles of real-time PCR. Veterinary PCR Diagnostics, Basseterre: Bhentam E-Books 2012:3-6.

28. Hatrick CD, Eakle S, Bird WF. Clinical applications for dental assistants and dental hygienist (3rd ed). Louis: Saunders Elsevier 2015:97,106-7.

29. Cebi N, Durak, MZ, Toker OS, Sagdic O, Arici M. An evaluation of fourier transforms infrared spectroscopy method for the classification and discrimination of bovine, porcine and fish gelatins. Food Chem 2016;90:10-13. 